Prepared in cooperation with the Nisqually Indian Tribe

\title{
Suspended Sediment Delivery to Puget Sound from the Lower Nisqually River, Western Washington, July 2010-November 2011
}

Scientific Investigations Report 2016-5062 
Cover: Downstream view of the lower Nisqually River, approximately 1 kilometer upstream of the river entrance into Puget Sound, Washington. Photograph by Christopher A. Curran, U.S. Geological Survey, March 29, 2016. 


\section{Suspended Sediment Delivery to \\ Puget Sound from the Lower Nisqually \\ River, Western Washington, \\ July 2010-November 2011}

By Christopher A. Curran, Eric E. Grossman, Christopher S. Magirl, and James R. Foreman

Prepared in cooperation with the Nisqually Indian Tribe

Scientific Investigations Report 2016-5062 


\title{
U.S. Department of the Interior SALLY JEWELL, Secretary
}

\section{U.S. Geological Survey Suzette M. Kimball, Director}

\author{
U.S. Geological Survey, Reston, Virginia: 2016
}

For more information on the USGS - the Federal source for science about the Earth, its natural and living resources, natural hazards, and the environment—visit http://www.usgs.gov or call 1-888-ASK-USGS.

For an overview of USGS information products, including maps, imagery, and publications, visit http://store.usgs.gov.

Any use of trade, firm, or product names is for descriptive purposes only and does not imply endorsement by the U.S. Government.

Although this information product, for the most part, is in the public domain, it also may contain copyrighted materials as noted in the text. Permission to reproduce copyrighted items must be secured from the copyright owner.

Suggested citation:

Curran, C.A., Grossman, E.E., Magirl, C.S., and Foreman, J.R., 2016, Suspended sediment delivery to Puget Sound from the lower Nisqually River, western Washington, July 2010-November 2011: U.S. Geological Survey Scientific Investigations Report 2016-5062, 17 p., http://dx.doi.org/10.3133/sir20165062.

ISSN 2328-0328 (online) 


\section{Contents}

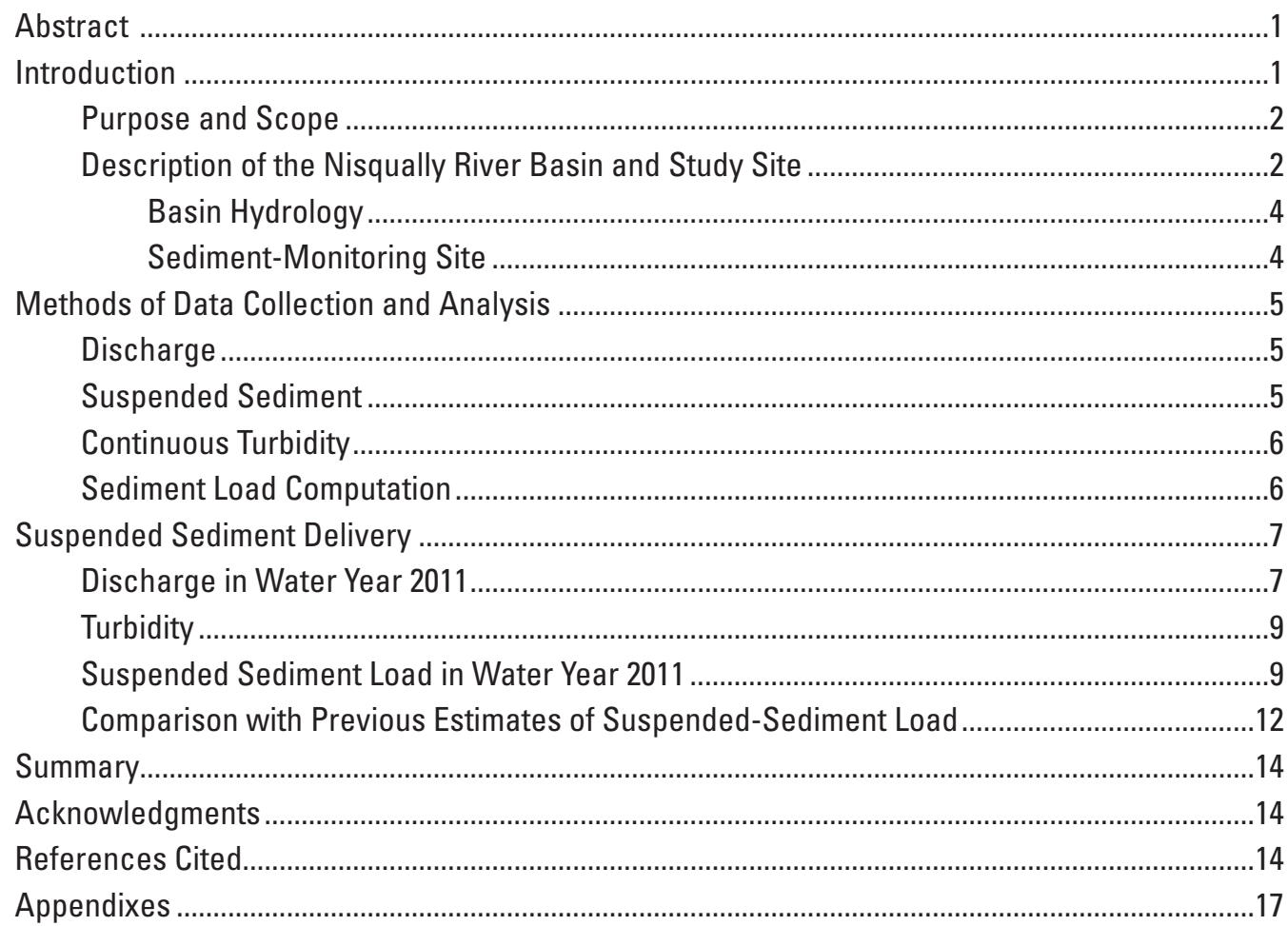

Appendix A. Daily Suspended-Sediment Concentrations and Loads at Nisqually River near Yelm, Washington (USGS Sediment Monitoring Site 12089970), July 25, 2010-November 30, 2011.

Appendix B. Continuous 15-Minute Turbidity Data at Nisqually River near Yelm, Washington (USGS Sediment Monitoring Site 12089970), July 25, 2010

November 30, 2011.

Appendix C. Data and Equations Used for Applying a Cross-Section Correction to Suspended-Sediment Concentrations of Isco Pump Samples..

Appendix D. Regression Model Used for Estimating Suspended-Sediment Concentration from Discharge. 


\section{Figures}

1. Map showing U.S. Geological Survey streamgages and sediment-monitoring site in the Nisqually River Basin, western Washington

2. Photographs of sediment sampling equipment, sample intake area at edge of active channel, and turbidity-monitoring installation, at the U.S. Geological Survey sediment-monitoring site Nisqually River near Yelm (12089970), Nisqually River Basin, western Washington, March 10, 2011.

3. Graph showing monthly mean discharges at U.S. Geological Survey streamgages in water year 2011 relative to long-term mean monthly discharges for each streamgage, Nisqually River Basin, western Washington

4. Graphs showing daily precipitation at U.S. Geological Survey streamgage Nisqually River near National (12082500) and daily mean discharge of the Nisqually River at U.S. Geological Survey streamgages 12082500, 12086500, 12089208, and 12089500 , and daily mean discharge estimated at sediment-monitoring site 12089970, Nisqually River Basin, western Washington, water year 2011

5. Graph showing number of times daily mean discharge exceeded 190 cubic meters per second in a water year based on 57 years of discharge record at U.S. Geological Survey streamgage Nisqually River at McKenna (12089500), Nisqually River Basin, western Washington.

6. Graph showing regression models for estimating suspended-sediment concentration (SSC) and fine suspended-sediment concentration from turbidity at the Nisqually River near Yelm (site 12089970), western Washington...

7. Graphs showing daily suspended-sediment concentrations as determined from field samples and continuous turbidity, and discharge at Nisqually River near Yelm (site 12089970), western Washington, August 1, 2010-November 30, 2011

8. Graph showing discharge and cumulative suspended-sediment load calculated for sediment-monitoring site (Nisqually River near Yelm, 12089970), western Washington, water year 2011

9. Graph showing regression model for estimating suspended-sediment load from river discharge at sediment-monitoring site (Nisqually River near Yelm, 12089970), western Washington.

10. Graph showing annual and maximum 2-day totals of suspended-sediment load at sediment-monitoring site Nisqually River near Yelm (12089970), and the ratio of annual peak discharge to annual mean discharge at streamgage Nisqually River at McKenna (12089500), western Washington, water years 1980-2014. 


\section{Tables}

1. Summary of discharge at U.S. Geological Survey streamgages and a sediment-monitoring site in the Nisqually River Basin, western Washington. 4

2. Instantaneous discharge measured at U.S. Geological Survey (USGS) sediment-monitoring site (Nisqually River near Yelm, 12089970) in 2010, compared with estimated discharge determined from summation of flows at upstream USGS streamgages (Nisqually River at McKenna, 12089500, and Centralia Power Canal near McKenna, 12089208), Nisqually River Basin, western Washington.

3. Suspended-sediment sample data from cross-section representative samples collected at USGS sediment-monitoring site (Nisqually River near Yelm, 12089970), western Washington, 2010-11.

4. Suspended-sediment concentrations and discharges reported by Nelson (1974) for samples collected at the Nisqually River near Nisqually, Washington, 1971-73, and computed suspended-sediment load used in developing a sediment-rating curve .......13

\section{Conversion Factors}

International System of Change not made Units to Inch/Pound

\begin{tabular}{|c|c|c|}
\hline Multiply & By & To obtain \\
\hline \multicolumn{3}{|c|}{ Length } \\
\hline meter (m) & 3.281 & foot (ft) \\
\hline kilometer (km) & 0.6214 & mile (mi) \\
\hline kilometer (km) & 0.5400 & mile, nautical (nmi) \\
\hline meter (m) & 1.094 & yard (yd) \\
\hline \multicolumn{3}{|c|}{ Area } \\
\hline square kilometer $\left(\mathrm{km}^{2}\right)$ & 247.1 & acre \\
\hline square kilometer $\left(\mathrm{km}^{2}\right)$ & 0.3861 & square mile $\left(\mathrm{mi}^{2}\right)$ \\
\hline \multicolumn{3}{|c|}{ Volume } \\
\hline milliliter (mL) & 0.033814 & ounce, fluid (fl. oz) \\
\hline Liter (L) & 0.2642 & gallon (gal) \\
\hline \multicolumn{3}{|c|}{ Flow rate } \\
\hline meter per second (m/s) & 3.281 & foot per second (ft/s) \\
\hline cubic meter per second $\left(\mathrm{m}^{3} / \mathrm{s}\right)$ & 70.07 & acre-foot per day (acre-ft/d) \\
\hline cubic meter per second $\left(\mathrm{m}^{3} / \mathrm{s}\right)$ & 35.31 & cubic foot per second $\left(\mathrm{ft}^{3} / \mathrm{s}\right)$ \\
\hline cubic meter per second $\left(\mathrm{m}^{3} / \mathrm{s}\right)$ & 22.83 & million gallons per day (Mgal/d) \\
\hline \multicolumn{3}{|c|}{ Mass } \\
\hline milligram (mg) & 0.00003527 & ounce, avoirdupois (oz) \\
\hline metric ton per year (t/d) & 1.102 & ton per day (ton/d) \\
\hline metric ton per year (t/yr) & 1.102 & ton per year (ton/yr) \\
\hline
\end{tabular}

Temperature in degrees Celsius $\left({ }^{\circ} \mathrm{C}\right)$ may be converted to degrees Fahrenheit $\left({ }^{\circ} \mathrm{F}\right)$ as

$$
{ }^{\circ} \mathrm{F}=\left(1.8 \times{ }^{\circ} \mathrm{C}\right)+32
$$




\section{Datums}

Vertical coordinate information is referenced to the North American Vertical Datum of 1988 (NAVD 88).

Horizontal coordinate information is referenced to the North American Datum of 1983 (NAD 83).

Altitude, as used in this report, refers to distance above the vertical datum.

\section{Abbreviations}

EDI Equal Discharge Increment

EWI Equal-Width Increment

FNU Formazin Nephelometric Unit

SSC suspended-sediment concentration

USGS U.S. Geological Survey

WY water year (0ctober 1-September 30) 


\title{
Suspended Sediment Delivery to Puget Sound in the Lower Nisqually River, Western Washington, July 2010-November 2011
}

\author{
By Christopher A. Curran, Eric E. Grossman, Christopher S. Magirl, and James R. Foreman
}

\section{Abstract}

On average, the Nisqually River delivers about 100,000 metric tons per year (t/yr) of suspended sediment to Puget Sound, western Washington, a small proportion of the estimated 1,200,000 metric tons (t) of sediment reported to flow in the upper Nisqually River that drains the glaciated, recurrently active Mount Rainier stratovolcano. Most of the upper Nisqually River sediment load is trapped in Alder Lake, a reservoir completed in 1945. For water year 2011 (October 1, 2010-September 30, 2011), daily sediment and continuous turbidity data were used to determine that $106,000 \mathrm{t}$ of suspended sediment were delivered to Puget Sound, and 36 percent of this load occurred in 2 days during a typical winter storm. Of the total suspended-sediment load delivered to Puget Sound in the water year 2011, 47 percent was sand (particle size $>0.063$ millimeters), and the remainder (53 percent) was silt and clay. A sediment-transport curve developed from suspended-sediment samples collected from July 2010 to November 2011 agreed closely with a curve derived in 1973 using similar data-collection methods, indicating that similar sediment-transport conditions exist. The median annual suspended-sediment load of 73,000 $t$ (water years 1980-2014) is substantially less than the average load, and the correlation (Pearson's $r=0.80, p=8.1 \mathrm{E}-9$, $n=35$ ) between annual maximum 2-day sediment loads and normalized peak discharges for the period indicates the importance of wet years and associated peak discharges of the lower Nisqually River for sediment delivery to Puget Sound. The magnitude of peak discharges in the lower Nisqually River generally is suppressed by flow regulation, and relative to other free-flowing, glacier-influenced rivers entering Puget Sound, the Nisqually River delivers proportionally less sediment because of upstream sediment trapping from dams.

\section{Introduction}

Fluvial sediment delivery is fundamental to the formation of river deltas that support critical estuarine habitat for fish and ecosystem development and in Puget Sound can both benefit and threaten estuarine ecosystems (Czuba and others, 2011). Understanding the rate of sediment delivery in rivers entering Puget Sound is important in the assessment of the resiliency of nearshore ecosystems threatened by sea level rise and for predicting the efficacy of present and future nearshore restoration efforts (Cereghino and others, 2012).

The Nisqually River flows into southern Puget Sound providing important riverine and estuarine ecological function. Because of Tribal and Federal land holdings, much of the lower Nisqually River near Puget Sound contains a still-functioning riparian floodplain (Collins and others, 2012), and a major restoration project was completed in 2009 on the Nisqually River Delta to further improve the ecological health of the lower river corridor (U.S. Fish and Wildlife Service, 2010). Compared to other rivers entering Puget Sound (Czuba and others, 2011), the lower Nisqually River carries a relatively light sediment load because of substantial sediment accumulation in Alder Lake, a reservoir upstream of the 101-m-high Alder Dam, completed in 1945. Before 1945, the natural sediment load in the lower Nisqually River likely was suppressed by the predecessor to Alder Dam, the 11-m-high La Grande Dam completed in 1912 (Czuba and others, 2012a). In contrast, the sediment load in the Nisqually River upstream of Alder Lake is relatively large because of sediment generated from Mount Rainier (Czuba and others, 2012a). 
Numerous geologic and sediment-transport studies have described the formative fluvial geomorphology of the Nisqually River or estimated the sediment load in the river and its tributaries. Nelson (1974) published a study of sediment measurements in the Nisqually and Deschutes River Basins, sampling suspended sediment from 1971 to 1972 at 16 sites. Downstream of Alder Lake, Nelson (1974) reported sediment loads of 95,000 t/yr for the Nisqually River at Nisqually and 91,000 t/yr for the Nisqually River above Powell Creek, near McKenna. Nelson (1974) also reported that mountainous catchments away from Mount Rainier produce a sediment yield at least one order of magnitude less than rivers directly draining Mount Rainier, and that catchments draining the Puget Lowland typically yield sediment at rates of about two orders of magnitude less than rivers draining Mount Rainier.

Based on bathymetric measurements of sediment accumulation in Alder Lake, Czuba and others (2012b) reported sediment yield similar to that of Nelson (1974) for the Nisqually River upstream of Alder Lake. Czuba and others (2012b) determined that from 1945 to 2011, the upper Nisqually River carried, on average, 1,200,000 $\pm 180,000$ t/yr of sediment and reported that 83-98 percent of this sediment load into Alder Lake originated from Mount Rainier. Czuba and others (2012b) also estimated that the trap efficiency of Alder Lake was $90 \pm 5$ percent and that the long-term mean sediment load transported past Alder Dam was $120,000 \pm 18,000 \mathrm{t} / \mathrm{yr}$. Using historical bathymetric surveys of Alder Lake, Czuba and others (2012b) reported that the average sediment load in the upper Nisqually River was just $860,000 \pm 300,000 \mathrm{t} / \mathrm{yr}$ from 1956 to 1985, indicating that sediment loads from Mount Rainier from 1956 to 1985 were less than the long-term average. This observation is notable because sediment sampled in 1971 and 1972 (Nelson, 1974) may have reflected sediment-transport conditions less in magnitude than the long-term mean.

\section{Purpose and Scope}

This report documents the timing and quantity of suspended-sediment load delivered by the Nisqually River to Puget Sound for July 25, 2010-November 30, 2011, which includes water year 2011 (October 1, 2010-September 30, 2011), for use in conjunction with nearshore circulation models to assess the sedimentation potential and efficacy of restoration efforts in the Nisqually River Delta. Sediment data collected in this study were used to develop sediment rating curves for estimating suspended-sediment load as a function of discharge and suspended-sediment concentration as a function of turbidity. Comparisons with a previous, similar study (Nelson, 1974) were made to assess differences in sediment-transport conditions and to estimate the mean annual suspended-sediment load delivered by the river to Puget Sound. Hydrology for the lower Nisqually River is examined from the long-term record of U.S. Geological Survey (USGS) streamgages in the basin and is used to provide a hydrologic context for the results of 2011 sediment loads. Turbidity is used as a surrogate measurement for suspended-sediment concentration (SSC) and, with sediment sample data, is used for assessing seasonal characteristics of sediment transport. This report includes the results of sediment-sample concentrations and particle size, and continuous turbidity data collected from July 2010 to November 2011.

\section{Description of the Nisqually River Basin and Study Site}

The Nisqually River is in the southeastern region of Puget Sound, a marine water body in western Washington formed as a result of Pleistocene glaciation (fig. 1; Booth, 1994; Porter and Swanson, 1998). The Nisqually River drains the Cascade Range, a part of the Puget Lowland, and the southwestern flank of Mount Rainier, a 4,392-m glaciated, recurrently active volcano (Crandell, 1971; Nelson, 1974; Sisson and Vallance, 2008; Czuba and others, 2012b). The Nisqually River formed after the retreat of the Puget Lobe of the Cordilleran Ice Sheet from the Puget Lowland about 16,00017,000 years ago (Porter and Swanson, 1998). In establishing its late-Pleistocene course toward Puget Sound, the river incised into glacial till deposits (Collins and Montgomery, 2011) with a slope adequate to convey the large sediment loads originating from Mount Rainier. Active volcanism at Mount Rainier during the Holocene (Crandell, 1971; Scott and others, 1995; Sisson and Vallance, 2008) spawned multiple lahars, some large enough to travel to Puget Sound (Scott and others, 1995). Large-scale volcanism and associated increased sedimentation has not occurred on Mount Rainier in the past 150 years, but rainfall-induced debris flows from Mount Rainier and large floods have promoted ample sediment transport filling a portion of Alder Lake (Czuba and others, 2012b). The lower $5 \mathrm{~km}$ of the Nisqually River and its estuary occupy a former marine embayment of Puget Sound, acting as a Holocene sediment deposition zone; the river delta is the product of sediment deposition from the Nisqually River during the Holocene (Collins and Montgomery, 2011).

Discharge in the lower Nisqually River is regulated by the 100-m-high Alder Dam and smaller La Grande Dam, each owned and operated by Tacoma Power for flood control and hydroelectric power generation. The three primary tributaries draining Mount Rainier in the Nisqually River Basin are the mainstem Nisqually River, Kautz Creek, and Tahoma Creek. Major tributaries Mineral Creek and the Little Nisqually River enter upstream of Alder Dam and drain the Cascade Range away from Mount Rainier. Downstream of Alder Dam, the Mashel River is the only sizeable Nisqually River tributary draining mountainous terrain. Tributaries Ohop, Tanwax, and Muck Creeks all enter downstream of the Mashel River, but these tributaries drain predominantly the low-gradient Puget Lowland and sediment loads in these tributaries are relatively small (Nelson, 1974). 


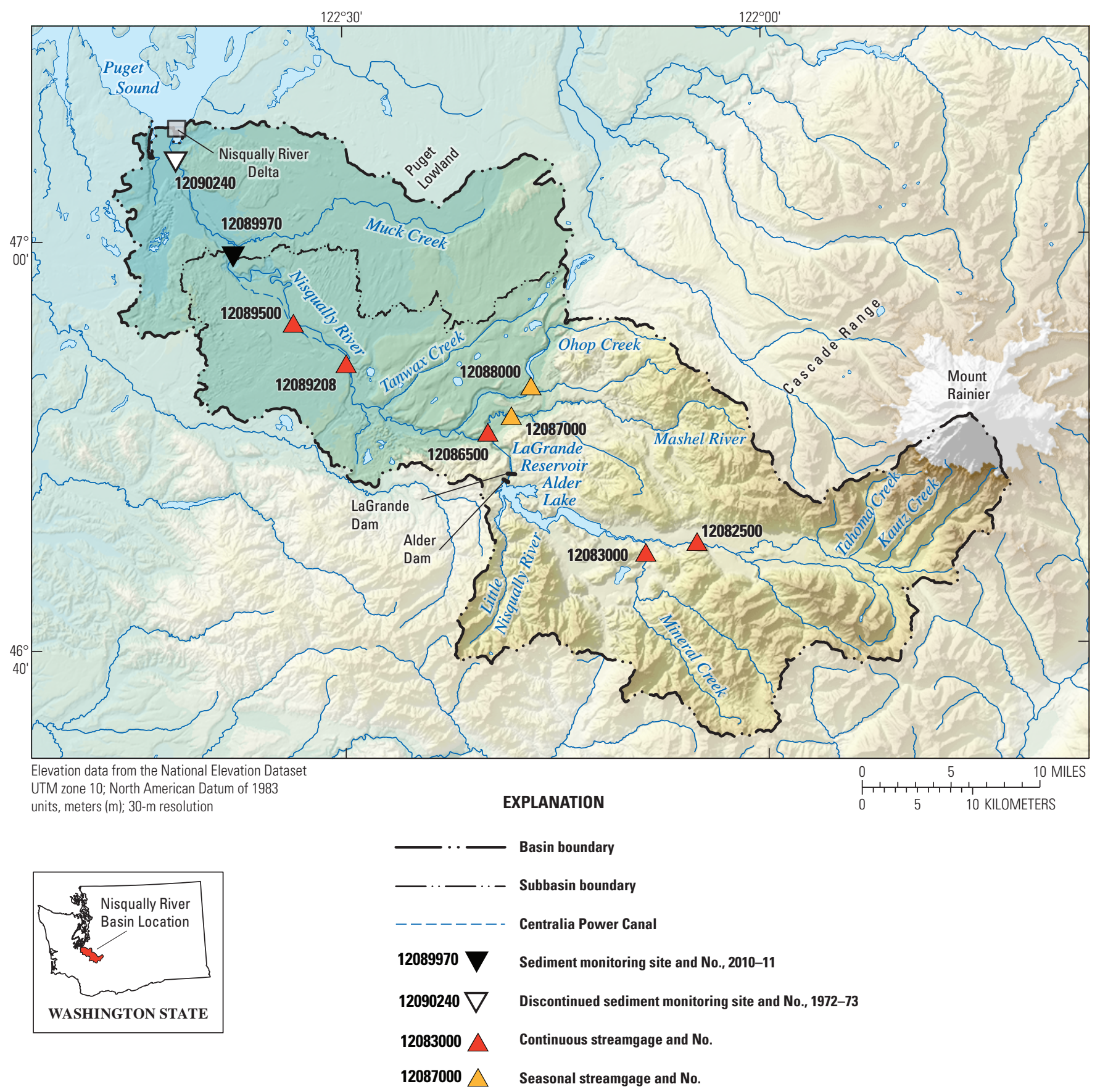

Figure 1. U.S. Geological Survey streamgages and sediment-monitoring site in the Nisqually River Basin, western Washington.

The climate of the Nisqually River Basin is predominantly wet and temperate (National Oceanic and Atmospheric Administration, 2010). The prevailing wind direction is from the south or southwest during the rainy season (October-June) and from the northwest during the relatively dry summer from July to September. During the winter, cold air from the Canadian interior occasionally flows southward, covering the region. The average January maximum temperature in the Puget Lowland is about $6{ }^{\circ} \mathrm{C}$ $\left(43^{\circ} \mathrm{F}\right)$ and the minimum temperature is about $-1^{\circ} \mathrm{C}\left(30^{\circ} \mathrm{F}\right)$.
During July, the average maximum temperature is about $24{ }^{\circ} \mathrm{C}$ $\left(75^{\circ} \mathrm{F}\right.$ ) and the average minimum temperature is about $10^{\circ} \mathrm{C}$ $\left(50^{\circ} \mathrm{F}\right)$. Annual precipitation in the Puget Lowlands is about $1,000 \mathrm{~mm}$ (40 in.), and the winter season snowfall is about 380 mm (15 in.). Precipitation increases with altitude; annual rainfall in the Cascade Range in high-altitude catchments typically is 1,550-2,500 mm (60-100 in.), and total annual snowfall is between 10 and $15 \mathrm{~m}$ (400-600 in.) at altitudes of 1,200-1,600 m (4,000-5,500 ft) (National Oceanic and Atmospheric Administration, 2010). 


\section{Basin Hydrology}

Mean annual discharge for the Nisqually River near National (USGS streamgage 12082500) is $22.0 \mathrm{~m}^{3} / \mathrm{s}\left(777 \mathrm{ft}^{3} / \mathrm{s}\right)$ for the period of 1943-2014 (72 years), with dominant hydrologic inputs from rainfall in winter and snowmelt in spring and summer (table 1). Downstream of Alder Lake, the mean annual discharge for the Nisqually River at McKenna (USGS streamgage 12089500 ) is $36.9 \mathrm{~m}^{3} / \mathrm{s}\left(1,301 \mathrm{ft}^{3} / \mathrm{s}\right)$. Late summer and autumn discharge is sustained by groundwater and glacial melt from Mount Rainier. The largest peak-flow events in the basin are caused by heavy autumn or winter precipitation associated with atmospheric rivers, strong synoptic systems from the Pacific Ocean that tap into tropical moisture sources (Neiman and others, 2011).

In the upper basin, the largest recorded peak discharge occurred in November 2006 during a large atmospheric river that caused widespread damage to Mount Rainier National Park (Czuba and others, 2012b). The peak discharge in the upper basin (Nisqually River near National, USGS streamgage 12082500) during the November 2006 event was $617 \mathrm{~m}^{3} / \mathrm{s}\left(21,800 \mathrm{ft}^{3} / \mathrm{s}\right)$. Widespread flooding also affected the region in February 1996 when discharge peaked at $600 \mathrm{~m}^{3} / \mathrm{s}$ $\left(21,200 \mathrm{ft}^{3} / \mathrm{s}\right)$ on the Nisqually River near National. Smaller peak-flow events in the upper basin usually occur in late spring and early summer with the seasonal snowmelt. The lower basin is regulated by Alder Dam (constructed in 1945), which strongly affects the peak-flow hydrology. Although the February 1996 storm resulted in the peak discharge of record for the Nisqually River at McKenna (USGS streamgage $12089500)$ of $1,420 \mathrm{~m}^{3} / \mathrm{s}\left(50,000 \mathrm{ft}^{3} / \mathrm{s}\right)$, the 2006 peak discharge was more tightly controlled by regulation at Alder Dam and resulted in a discharge of $436 \mathrm{~m}^{3} / \mathrm{s}\left(15,400 \mathrm{ft}^{3} / \mathrm{s}\right)$. Hydrologic data at USGS streamgages typically are reported by water year, which is defined as the 12-month period October 1, for any given year through September 30, of the following year.

\section{Sediment-Monitoring Site}

The USGS sediment-monitoring site installed as part of this study, the Nisqually River near Yelm (site 12089970), is in the lower Nisqually River, $19.2 \mathrm{~km}$ upstream of the river mouth, $1.6 \mathrm{~km}$ downstream of the Centralia Power Canal outlet, and $15.8 \mathrm{~km}$ downstream of USGS streamgage Nisqually River at McKenna (12089500) (fig. 1). The lower Nisqually River is defined herein as the reach downstream of the outlet of the Centralia Power Canal about $20.8 \mathrm{~km}$ upstream of the mouth of the river at Puget Sound. The mixeddiurnal tidal influence in the lower river extends to about $5 \mathrm{~km}$ upstream of the mouth. The largest tributary in the lower river, Muck Creek, is $1.5 \mathrm{~km}$ downstream of the sedimentmonitoring site, and remains a potential sediment source not included in this study. The drainage area of the basin at the sediment monitoring site is $1,520 \mathrm{~km}^{2}$, and 50 percent of this area is upstream of the Alder and La Grande Dams.

Table 1. Summary of discharge at U.S. Geological Survey streamgages and a sediment-monitoring site in the Nisqually River Basin, western Washington.

[Mean annual discharge and discharge data for water years 1973 and 2011 are available at http://waterdata.usgs.gov/wa/nwis/sw. Water year is defined as the

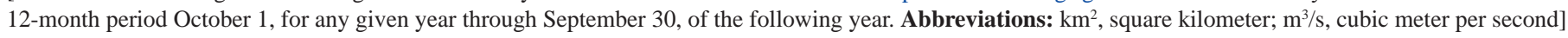

\begin{tabular}{|c|c|c|c|c|c|c|c|}
\hline \multirow{2}{*}{$\begin{array}{c}\text { Streamgage and No. or } \\
\text { sediment-monitoring site and No. }\end{array}$} & \multirow{2}{*}{$\begin{array}{c}\text { Drainage } \\
\text { area } \\
\left(\mathbf{k m}^{2}\right)\end{array}$} & \multirow{2}{*}{$\begin{array}{l}\text { Period of } \\
\text { discharge } \\
\text { record } \\
\text { (water year) }\end{array}$} & \multirow{2}{*}{$\begin{array}{c}\text { Mean } \\
\text { annual } \\
\text { discharge } \\
\left(\mathrm{m}^{3} / \mathrm{s}\right)\end{array}$} & \multicolumn{2}{|c|}{$\begin{array}{c}\text { Discharge, } \\
\text { water year } 1973\end{array}$} & \multicolumn{2}{|c|}{$\begin{array}{c}\text { Discharge, } \\
\text { water year } 2011\end{array}$} \\
\hline & & & & $\begin{array}{l}\text { Mean } \\
\left(\mathrm{m}^{3} / \mathrm{s}\right)\end{array}$ & $\begin{array}{l}\text { Peak } \\
\left(\mathrm{m}^{3} / \mathrm{s}\right)\end{array}$ & $\begin{array}{l}\text { Mean } \\
\left(\mathrm{m}^{3} / \mathrm{s}\right)\end{array}$ & $\begin{array}{l}\text { Peak } \\
\left(\mathrm{m}^{3} / \mathrm{s}\right)\end{array}$ \\
\hline Nisqually River near National (12082500) & 344 & 1943-2014 & 22.0 & 17.0 & 218 & 28.6 & 256 \\
\hline Nisqually River at La Grande (12086500) & 756 & $\begin{array}{l}\text { 1907-1910, } \\
\text { 1920-1931, } \\
1944-2014\end{array}$ & 40.8 & 34.5 & ${ }^{12} 204$ & 53.5 & ${ }^{13} 309$ \\
\hline Centralia Power Canal near McKenna (12089208) & - & 1980-2014 & ${ }^{2} 15.8$ & - & - & 15.2 & ${ }^{12} 20.6$ \\
\hline Nisqually River near McKenna (12089500) & 1,339 & $\begin{array}{l}\text { 1948-1968, } \\
1978-2014\end{array}$ & 36.9 & - & - & 52.3 & ${ }^{13} 36$ \\
\hline Nisqually River near Yelm (12089970) & 1,520 & $1980-2014^{3}$ & 352.7 & - & - & ${ }^{3} 67.5$ & 3356 \\
\hline
\end{tabular}

${ }^{1}$ Discharge affected by regulation or diversion.

${ }^{2}$ Calculated from available discharge data.

${ }^{3}$ Estimated from the sum of discharge at streamgages 12089208 and 12089500 with consideration for time of travel. 


\section{Methods of Data Collection and Analysis}

\section{Discharge}

A 15-minute time series of discharge, required for calculating suspended-sediment loads, was estimated for the sediment-monitoring site Nisqually River near Yelm (site 12089970) from the summation of instantaneous (15-minute) discharge records at Nisqually River at McKenna (streamgage 12089500; http://waterdata.usgs.gov/nwis/uv?site_ no=12089500), $15.8 \mathrm{~km}$ upstream of the monitoring site, and Centralia Power Canal near McKenna (streamgage 12089208; http://waterdata.usgs.gov/wa/nwis/uv/?site_no=12089208), $23 \mathrm{~km}$ upstream of and where water is diverted from the main Nisqually River into the canal (fig. 1). To account for travel time in discharge between the upstream streamgages and the study site, a mean water velocity of $1.4 \mathrm{~m} / \mathrm{s}$ was estimated between the streamgages and the study site, and 15-minute discharge records were lagged by 3.25 and 4.5 hours for the records at streamgages 12089500 and 12089208, respectively. To evaluate the accuracy of the estimated record, discharge was measured on site with a tethered boat equipped with an acoustic Doppler current profiler (usually in conjunction with suspended-sediment sample collection) over a range of flow conditions, following methods outlined by Mueller and others (2013). Discharge measurements made on site were compared with the estimated 15-minute discharge record to ensure consistency (table 2) and differences were less than 5 percent.

\section{Suspended Sediment}

Suspended-sediment samples were collected at various times over a range of flows at Nisqually River near Yelm (12089970) during water year 2011. The Equal Discharge Increment (EDI) and Equal-Width Increment (EWI) methods (Edwards and Glysson, 1999) were used to collect discrete, cross-section representative samples using depth-integrated, isokinetic samplers (fig. 2A) approved by the Federal Interagency Sedimentation Program and used routinely by USGS personnel (Davis, 2005). Additionally, an Isco automated-pump sampler was used to collect daily point samples of suspended sediment. The sampler intake was placed at the edge of the active channel (fig. 2B), and the sampler was programmed to collect $200-\mathrm{mL}$ subsamples at 6-hour intervals, which were composited into a single daily $800 \mathrm{~mL}$ sample. A cross-section coefficient was used to account for potential bias in sample concentration due to the location of the sampler intake, and computed as the ratio of mean concentration in the cross section (from EDI or EWI samples) to the concentration of pumped samples (Edwards and Glysson, 1999). All samples were analyzed to determine the concentration of suspended sediment and the percentage of sand-size sediment (particles larger than $0.063 \mathrm{~mm}$ in size) at the USGS sediment laboratory at the Cascade Volcano Observatory in Vancouver, Washington.

Table 2. Instantaneous discharge measured at U.S. Geological Survey (USGS) sediment-monitoring site (Nisqually River near Yelm, 12089970) in 2010, compared with estimated discharge determined from summation of flows at upstream USGS streamgages (Nisqually River at McKenna, 12089500, and Centralia Power Canal near McKenna, 12089208), Nisqually River Basin, western Washington.

[E stimated discharge: Computed as the sum of discharges recorded at Nisqually River near McKenna (12089500) and Centralia Power Canal (12089208), adjusted for travel time. A bbreviations: $\mathrm{m}^{3} / \mathrm{s}$, cubic meter per second; m/s, meter per second]

\begin{tabular}{|c|c|c|c|c|c|}
\hline \multirow{2}{*}{ Date } & \multirow{2}{*}{ Local time } & \multicolumn{2}{|c|}{ Discharge $\left(\mathrm{m}^{3} / \mathrm{s}\right)$} & \multirow{2}{*}{$\begin{array}{c}\text { Percent } \\
\text { difference }\end{array}$} & \multirow{2}{*}{$\begin{array}{c}\text { Measured } \\
\text { mean water } \\
\text { velocity }(\mathrm{m} / \mathrm{s})\end{array}$} \\
\hline & & Measured & Estimated & & \\
\hline $09-10-2010$ & 1200 & 29.5 & 29.1 & 1.4 & 1.20 \\
\hline 09-29-2010 & 1430 & 27.6 & 27.5 & 0.4 & 1.13 \\
\hline $10-28-2010$ & 1030 & 46.2 & 46.2 & 0.0 & 1.34 \\
\hline $11-10-2010$ & 1115 & 48.1 & 46.9 & 2.6 & 1.32 \\
\hline $11-24-2010$ & 0930 & 80.8 & 77.0 & 4.9 & 1.42 \\
\hline $12-09-2010$ & 0930 & 98.7 & 98.4 & 0.3 & 1.54 \\
\hline $12-14-2010$ & 1300 & 129 & 130 & -0.8 & 1.8 \\
\hline
\end{tabular}




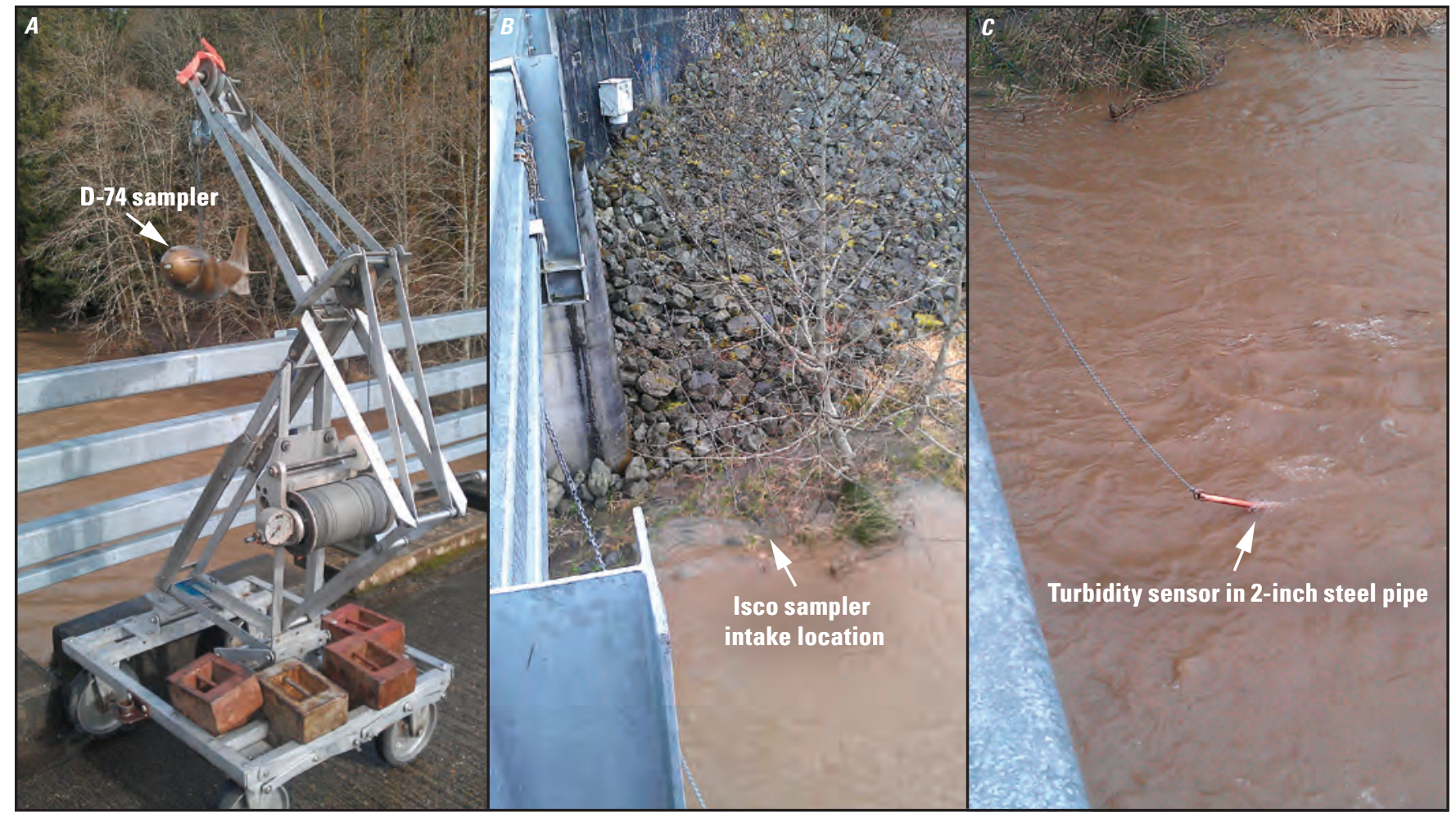

Figure 2. Sediment sampling equipment $(A)$, sample intake area at edge of active channel $(B)$, and turbidity-monitoring installation (C), at the U.S. Geological Survey sediment-monitoring site Nisqually River near Yelm (12089970), Nisqually River Basin, western Washington, March 10, 2011. Photographs by Christopher A. Curran, U.S. Geological Survey.

\section{Continuous Turbidity}

River turbidity was continuously monitored during most of water year 2011 in which sediment sampling was conducted, with the exception of intermittent periods when instrument failure or excessive fouling occurred, and during a 6-week period in January-February when the instrument was lost during a high-flow event. Turbidity was measured using a YSI-6136 turbidity sensor with an optimal range of 0 to 1,000 Nephelometric Turbidity Units (YSI, Inc., 2007). This sensor was housed in a 2-inch steel pipe suspended over the thalweg of the river in a boom-type mount from the downstream bridge rail (fig. 2C). This mounting arrangement allowed turbidity measurements in an actively flowing part of the river channel and decreased the likelihood of debris build-up around the sensor face or on the mounting hardware, which could foul sensor readings. Turbidity data were recorded at 15-minute intervals and the sensor was serviced approximately once per month for downloading data and performing cleaning and calibration checks.

\section{Sediment Load Computation}

A daily record of suspended-sediment load at the monitoring site (12089970) was determined for water year 2011 based on the suspended-sediment concentration (SSC) of field samples and the discharge record following methods described by Porterfield (1972) and Koltun and others (2006). For periods when Isco samples were not available, turbidity was used as a surrogate for SSC. A regression was developed between SSC from cross-section samples and concurrently measured turbidity following methods outlined by Rasmussen and others (2009). A 15-minute time series of SSC was computed by applying the regression equation with 15-minute turbidity data and, for consistency with the daily time-step of the Isco sampler, daily mean suspended-sediment concentrations were determined. For periods when neither turbidity data nor pump sampler data were available, SSC was computed from discharge at the sediment-monitoring site (12089970) using a regression equation developed for this purpose. 


\section{Suspended Sediment Delivery}

\section{Discharge in Water Year 2011}

Mean discharge at Nisqually River near National (streamgage 12082500) was 30 percent greater than average $\left(28.6 \mathrm{~m}^{3} / \mathrm{s}\left[1,010 \mathrm{ft}^{3} / \mathrm{s}\right]\right)$ in water year 2011 , and at Nisqually River at La Grande (12086500), mean discharge was 31 percent greater than average $\left(53.5 \mathrm{~m}^{3} / \mathrm{s}\right.$ [1,890 $\left.\mathrm{ft}^{3} / \mathrm{s}\right]$ ). Farther downstream at Nisqually River at McKenna (streamgage 12089500), which includes discharge from Mashel and Ohop Creeks, mean discharge was 42 percent greater than average $\left(52.3 \mathrm{~m}^{3} / \mathrm{s}\left[1,850 \mathrm{ft}^{3} / \mathrm{s}\right]\right)$ in water year 2011 and, for water diverted around the McKenna streamgage through the Centralia Power Canal, it was near average $\left(15.2 \mathrm{~m}^{3} / \mathrm{s}\right.$ [537 ft $\left.\left.3 / \mathrm{s}\right]\right)$. Seasonally, discharge in the Nisqually River upstream and downstream of reservoirs was greater than average for most months in water year 2011, except for February, when discharge was average. Discharge was substantially greater in January (+58-83 percent) and during the typical spring freshet period of April-June (+18-96 percent; fig. 3).

Examination of the hydrographs of daily mean discharge for all Nisqually River streamgages and the sediment-monitoring site in water year 2011, as shown in figure 4, indicates typical seasonal patterns of precipitationinduced discharge peaks and flow regulation (storage and release) from reservoir operations. Regulation of peak discharge was minimal during December and January storms, but for the rest of the year, peak discharges were moderated and did not occur downstream because of water storage behind dams. Discharge recorded at the McKenna streamgage (12089500) was greater than at the La Grande streamgage (12086500), particularly peak discharges, and represents contributions from Ohop and Mashel Creeks. The hydrograph for Nisqually River near Yelm (12089970) is estimated as the sum of daily mean discharges recorded at the McKenna and Centralia Canal streamgages.

In water year 2011, the instantaneous (15-minute) peak discharge at all streamgages in the Nisqually River Basin occurred on January 16, and at the McKenna streamgage (12089500), the instantaneous peak discharge was $346 \mathrm{~m}^{3} / \mathrm{s}$ $\left(12,200 \mathrm{ft}^{3} / \mathrm{s}\right)$ and the corresponding maximum daily mean discharge was $306 \mathrm{~m}^{3} / \mathrm{s}\left(10,800 \mathrm{ft}^{3} / \mathrm{s}\right)$. Although affected by flow regulation, the peak discharge at the McKenna streamgage (12089500) in water year 2011 has occurred on average about once every 2.3 years, as determined from USGS software PEAKFQ (Veilleux and others, 2014) and based on 58 years of record (1948-68, 1978-2014). On average, daily mean discharge at the McKenna streamgage has equaled or exceeded $190 \mathrm{~m}^{3} / \mathrm{s}\left(6,700 \mathrm{ft}^{3} / \mathrm{s}\right)$ three times per water year. In water year 2011, this discharge was exceeded for only 2 days (January17, 2011, for daily discharges of $306 \mathrm{~m}^{3} / \mathrm{s}$ $\left[10,800 \mathrm{ft}^{3} / \mathrm{s}\right]$ and $267 \mathrm{~m}^{3} / \mathrm{s}\left[9,430 \mathrm{ft}^{3} / \mathrm{s}\right]$, respectively), suggesting that in terms of the frequency, the number of substantial discharge events was less than average in water year 2011 (fig. 5).

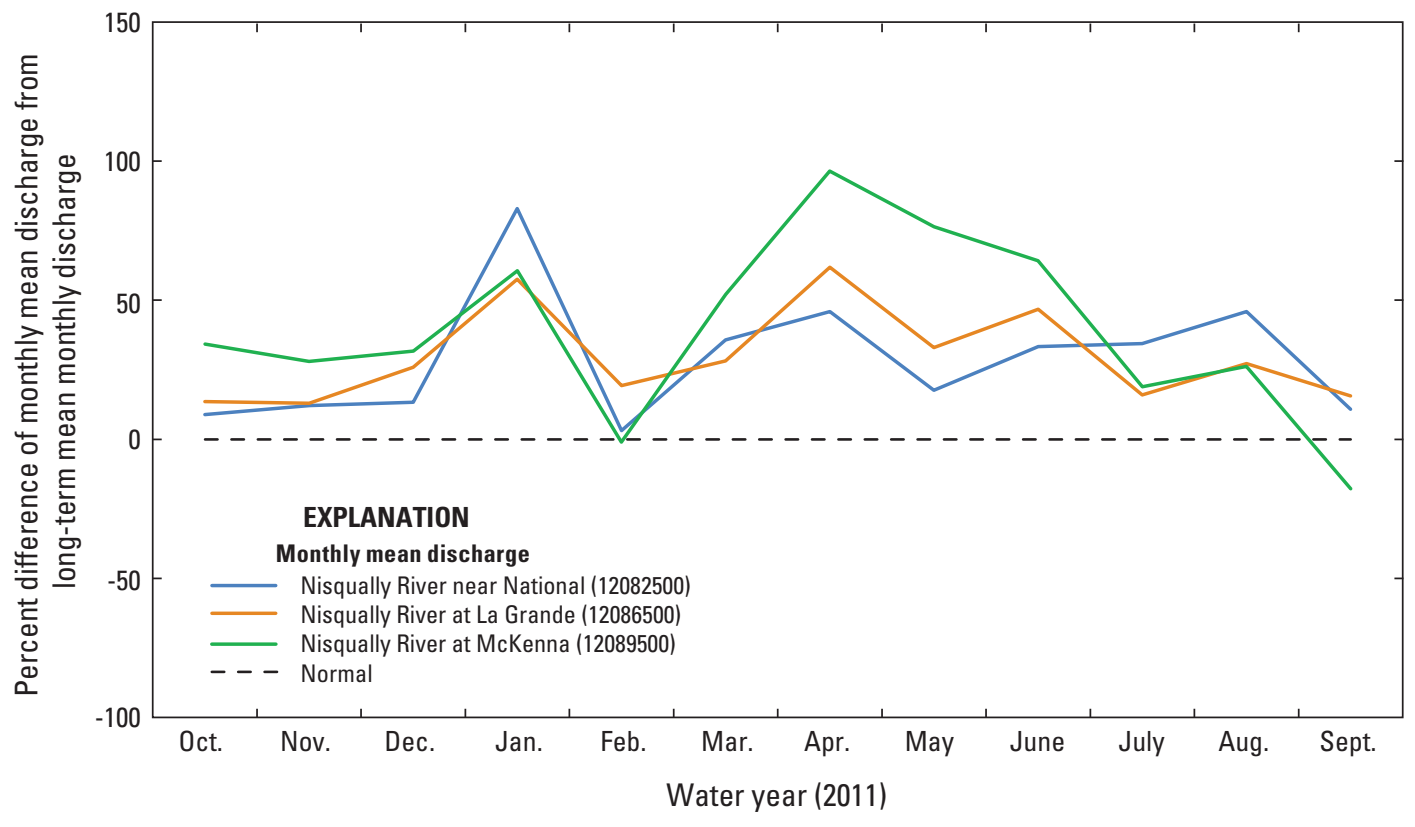

Figure 3. Monthly mean discharges at U.S. Geological Survey streamgages in water year 2011 relative to long-term mean monthly discharges for each streamgage, Nisqually River Basin, western Washington. 

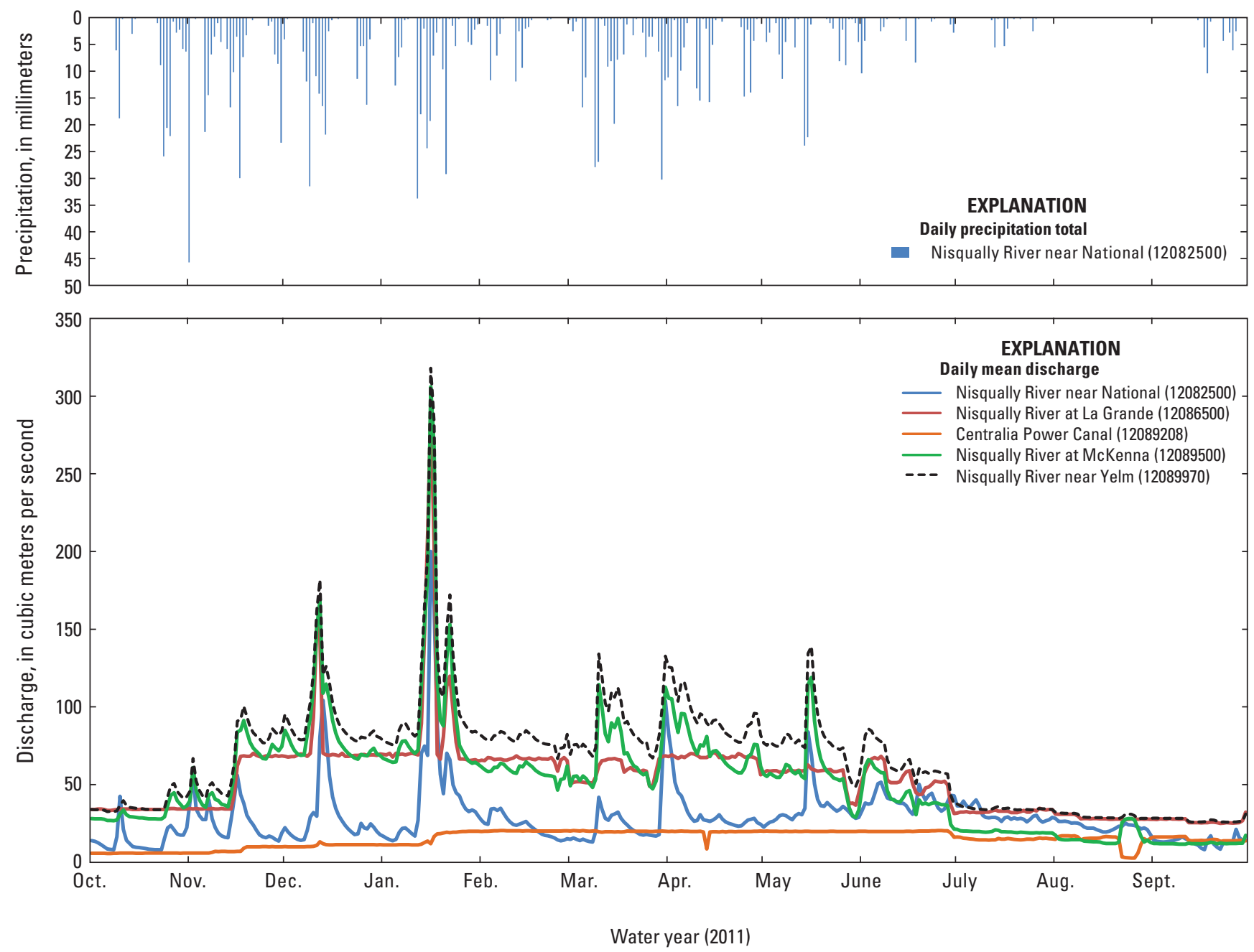

Figure 4. Daily precipitation at U.S. Geological Survey streamgage Nisqually River near National (12082500) and daily mean discharge of the Nisqually River at U.S. Geological Survey streamgages 12082500, 12086500, 12089208, and 12089500, and daily mean discharge estimated at sediment-monitoring site 12089970, Nisqually River Basin, western Washington, water year 2011.

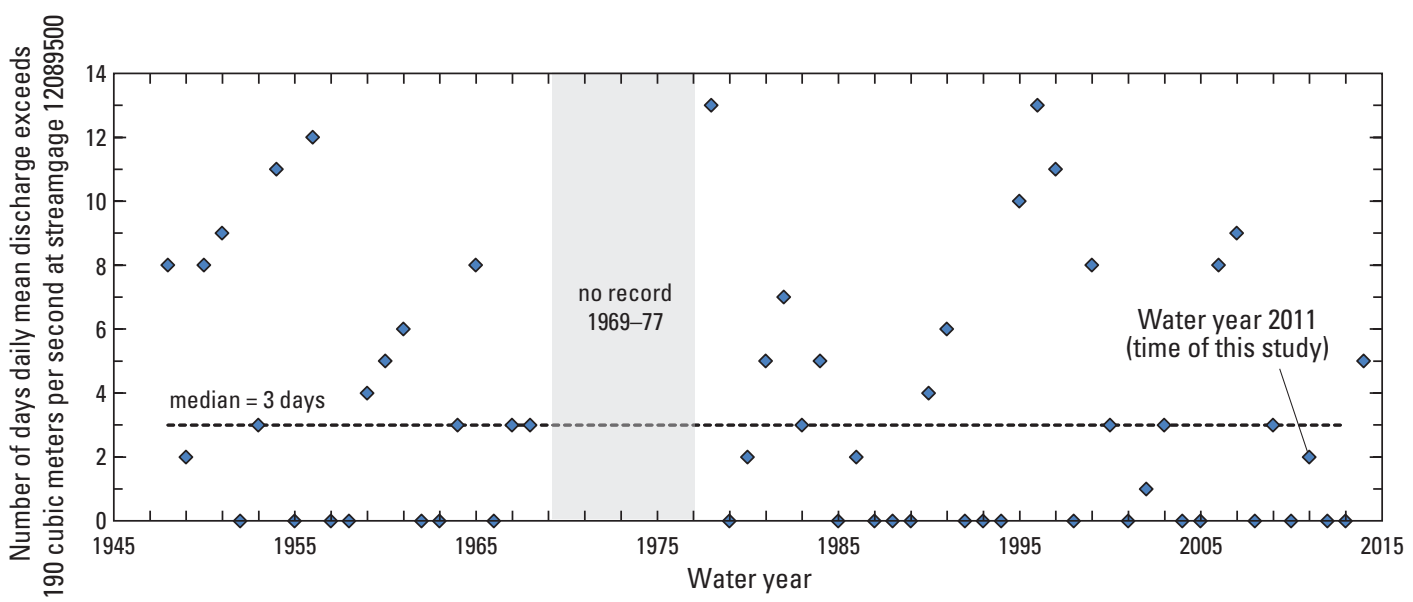

Figure 5. Number of times daily mean discharge exceeded 190 cubic meters per second in a water year (October 1-September 30) based on 57 years of discharge record (1943-68, 19782013) at U.S. Geological Survey streamgage Nisqually River at McKenna (12089500), Nisqually River Basin, western Washington. 


\section{Turbidity}

Although continuous 15-minute turbidity data were recorded for more than 76 percent of the study period $(36,175$ of 47,448 times), extended time gaps (as much as 38 days) occurred because of sensor fouling, malfunction or power loss, and equipment loss. A tabulation of daily median turbidity data determined from 15-minute data, as well as periods of missing data, is shown in appendix A. A notable time gap in the turbidity record occurred during January 14-February 21, 2011, when the turbidity sensor was lost during a winter storm; this gap included the occurrence of the annual peak discharge on January 16, 2011. The recorded 15-minute turbidity data are tabulated in appendix $\mathrm{B}$, the average turbidity was 14 Formazin Nephelometric Units (FNUs), and values ranged from 0.6 to 320 FNUs.

\section{Suspended Sediment Load in Water Year 2011}

From August 24, 2010, to September 30, 2011, suspended-sediment concentrations were obtained from 16 cross-section representative samples collected using EDI or
EWI sampling methods and from 167 point samples using an Isco sampler. The EDI and EWI samples were paired with concurrently recorded turbidity (when available), and a regression model was developed for estimating suspended-sediment concentration from turbidity (fig. 6). Daily suspended-sediment concentrations were computed at USGS sediment-monitoring site Nisqually River near Yelm (12089970) during July 25, 2010-November 30, 2011 (fig. 7C) based on a combination of daily Isco samples (fig. 7B) and the continuous turbidity record when daily Isco samples were not available. Isco sample SSCs were 1.4 to 4.4 times higher than concurrent EDI/EWI samples and this bias, caused by the location of the sampler intake in the cross-section, decreased with increasing SSC and discharge. In lieu of a single crosssection correction factor, a linear regression (appendix C) relating the SSC of Isco samples to concurrent EWI samples was used to correct for bias in Isco sample SSC. For days when neither Isco sample data nor turbidity data were available, SSC was estimated from discharge (appendix D); during the water year 2011, this occurred on 29 days: October 1-8, 2010, February 8-9, March 6-7, June 26, 29, July 2, August 2-3 September 5, 2011.

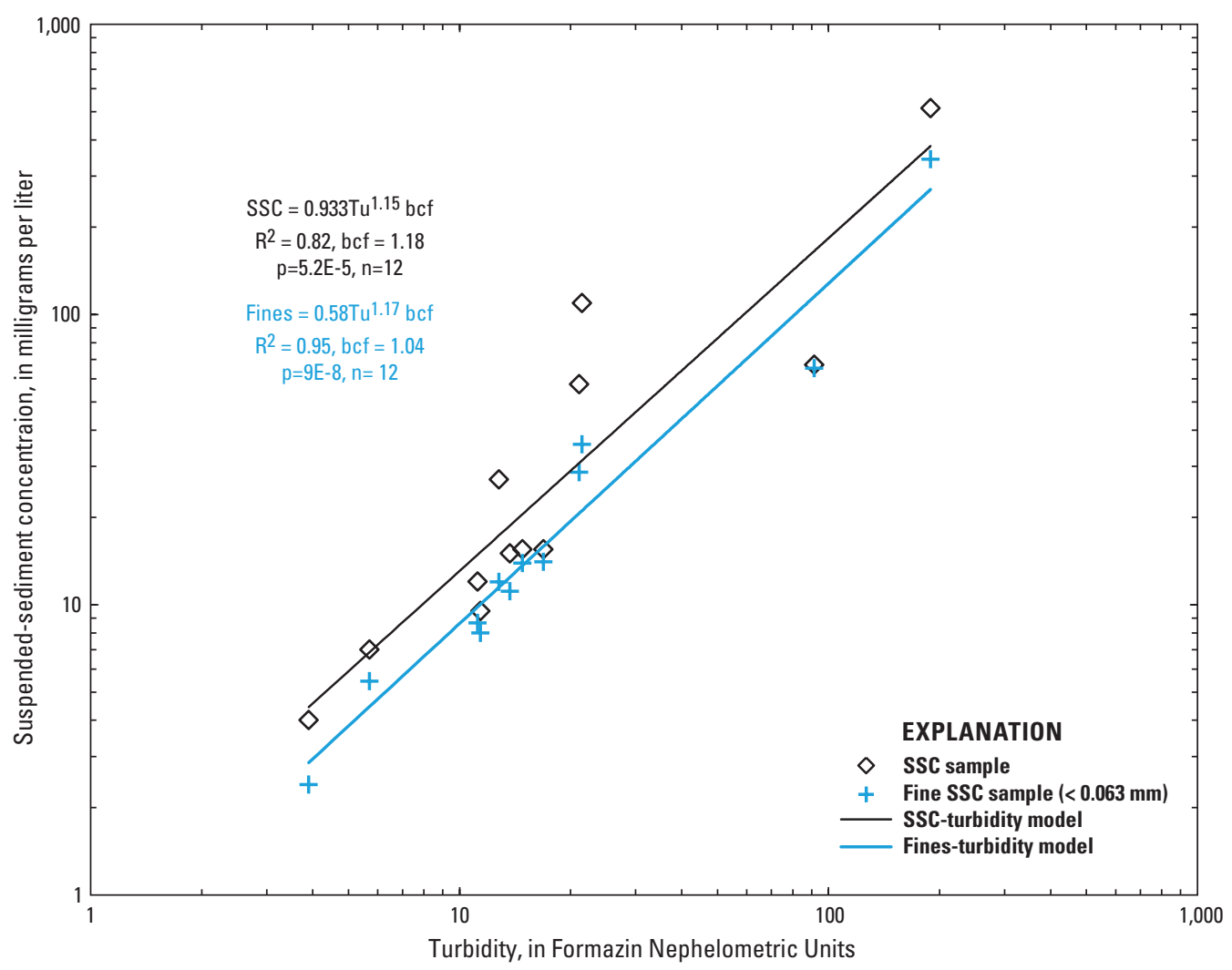

Figure 6. Regression models for estimating suspended-sediment concentration (SSC) and fine suspended-sediment concentration (fines, size less than 0.063 millimeters) from turbidity (YSI-6136 turbidity sensor) at the Nisqually River near Yelm (site 12089970), western Washington. 


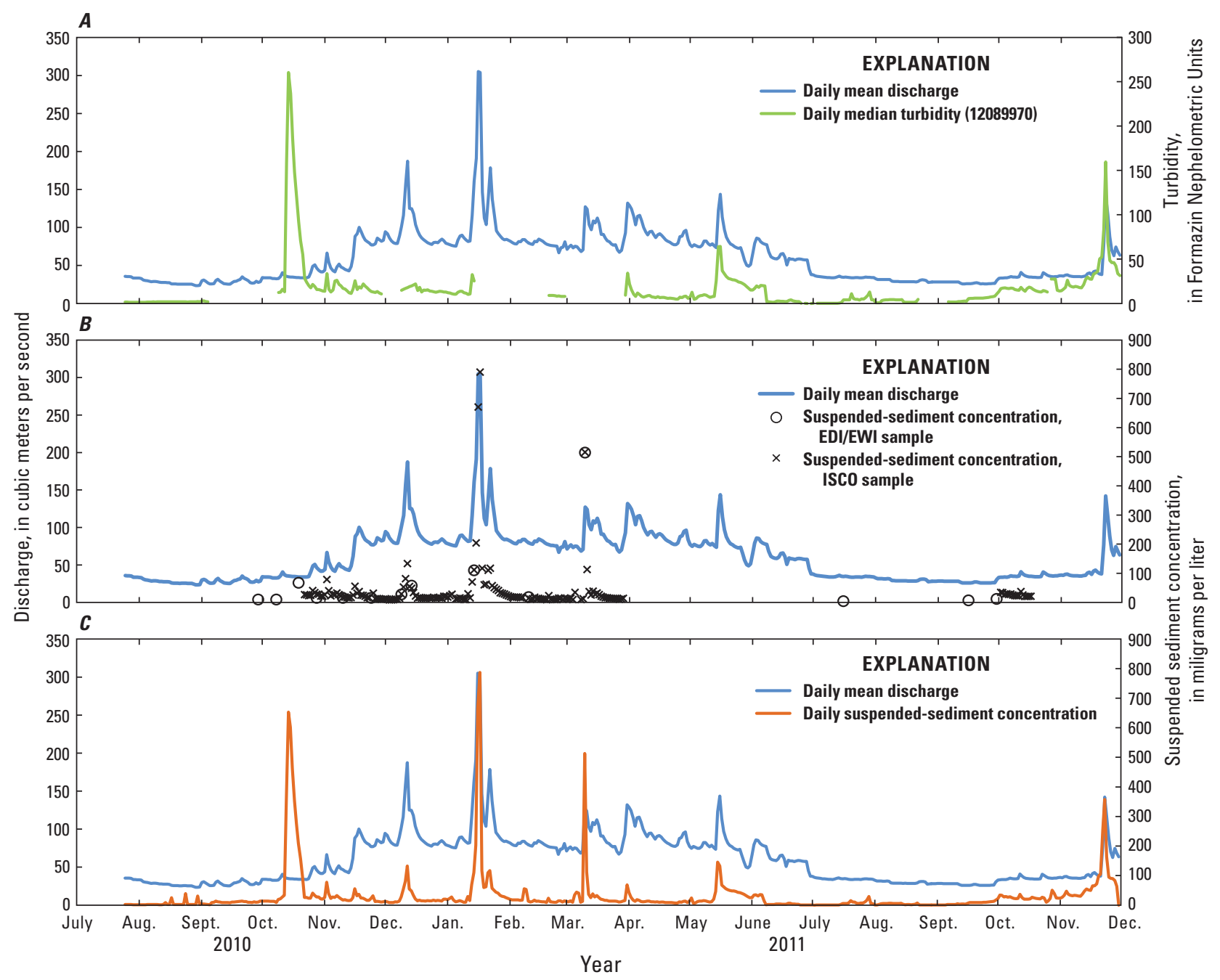

Figure 7. Daily suspended-sediment concentrations as determined from field samples and continuous turbidity, and discharge at Nisqually River near Yelm (site 12089970), western Washington, August 1, 2010 November 30, 2011.

The daily SSC for the monitoring period ranged from 1 to $787 \mathrm{mg} / \mathrm{L}$; the average daily SSC was $33 \mathrm{mg} / \mathrm{L}$ and the median daily SSC was $13 \mathrm{mg} / \mathrm{L}$. The maximum daily SSC was derived from Isco samples collected during a winter storm on January 17, 2011, for which the daily suspended-sediment load was 20,700 t. From October 13 to 19, 2010, a turbidity event occurred during seasonally low flows and is attributed to the release of turbid water from Alder Reservoir to maintain instream flows; the maximum daily SSC for this period was $651 \mathrm{mg} / \mathrm{L}$ on October 14, 2010. The suspended-sediment concentrations for discrete samples collected using the EDI or EWI methods are shown in table 3.

Daily suspended-sediment loads computed at sedimentmonitoring site (Nisqually River near Yelm,12089970) for water year 2011 are shown in figure 8. The computed annual load of 104,000 t does not include the contribution from Muck Creek. Suspended-sediment load for Muck Creek is estimated at 2,000 $\mathrm{t}$ in water year 2011 based on the previous calculation by Nelson (1974) of 1,500 t/yr and a discharge weighting factor of 1.3 (to reflect the observed 30 percent greater than normal discharge) for the water year 2011. Thus, total suspended-sediment delivery from Nisqually River to Puget Sound for water year 2011 is 106,000 t. Of this suspended-sediment load, 36 percent (38,300 t) was generated in 2 days (January 16-17) during a typical winter storm. Of the total suspended-sediment load calculated for the water year 2011, 47 percent was sand (particle size $>0.063 \mathrm{~mm}$ ) and the remainder (53 percent) was silt and clay. 
Table 3. Suspended-sediment sample data from cross-section representative samples collected at USGS sediment-monitoring site (Nisqually River near Yelm, 12089970), western Washington, 2010-11.

[Discharge: Computed as the sum of discharges recorded at Nisqually River at McKenna (12089500) and Centralia Power Canal (12089208), adjusted for travel time. A bbreviations: $\mathrm{mg} / \mathrm{L}$, milligram per liter; mm, millimeter; $\mathrm{m}^{3} / \mathrm{s}$, cubic meter per second; FNU, Formazin Nephelometric Unit; <less than; -, unavailable]

\begin{tabular}{c|c|c|c|c|c|c}
\hline Date & Local time & $\begin{array}{c}\text { Suspended- } \\
\text { sediment } \\
\text { concentration } \\
\text { (mg/L) }\end{array}$ & $\begin{array}{c}\text { Percentage } \\
\text { of fines } \\
(<\mathbf{0 . 0 6 2 5} \mathbf{~ m m})\end{array}$ & $\begin{array}{c}\text { Discharge } \\
\left(\mathbf{m}^{3} \mathbf{s}\right)\end{array}$ & $\begin{array}{c}\text { Suspended- } \\
\text { sediment load } \\
\text { (metric tons } \\
\text { per day) }\end{array}$ & $\begin{array}{c}\text { Turbidity } \\
\text { (FNU) }\end{array}$ \\
\hline $08-24-2010$ & 1515 & 2 & - & 25.6 & 4 & - \\
$09-10-2010$ & 0945 & 6 & 68 & 29.3 & 15 & - \\
$09-29-2010$ & 1515 & 10 & 90 & 27.4 & 24 & - \\
$10-08-2010$ & 1345 & 10 & 84 & 32.7 & 31 & 11.4 \\
$10-19-2010$ & 1230 & 67 & 97 & 34.0 & 191 & 91.6 \\
$10-28-2010$ & 1215 & 16 & 90 & 45.3 & 63 & 14.8 \\
$11-10-2010$ & 1245 & 16 & 91 & 46.6 & 60 & 16.9 \\
$11-24-2010$ & 1045 & 15 & 74 & 76.2 & 92 & 13.7 \\
$12-09-2010$ & 1015 & 27 & 44 & 102 & 230 & 12.8 \\
$12-14-2010$ & 1345 & 58 & 50 & 129 & 646 & 21.1 \\
$01-14-2011$ & 1030 & 110 & 33 & 154 & 1,490 & 21.5 \\
$02-10-2011$ & 1015 & 18 & 42 & 76.6 & 119 & - \\
$03-10-2011$ & 1445 & 514 & 67 & 159 & 6,930 & 189 \\
$07-16-2011$ & 1030 & 4 & - & 34.6 & 12 & 3.9 \\
$09-16-2011$ & 0915 & 7 & 78 & 25.9 & 16 & 5.7 \\
$09-30-2011$ & 1145 & 12 & 72 & 30.2 & 31 & 11.2 \\
\hline
\end{tabular}

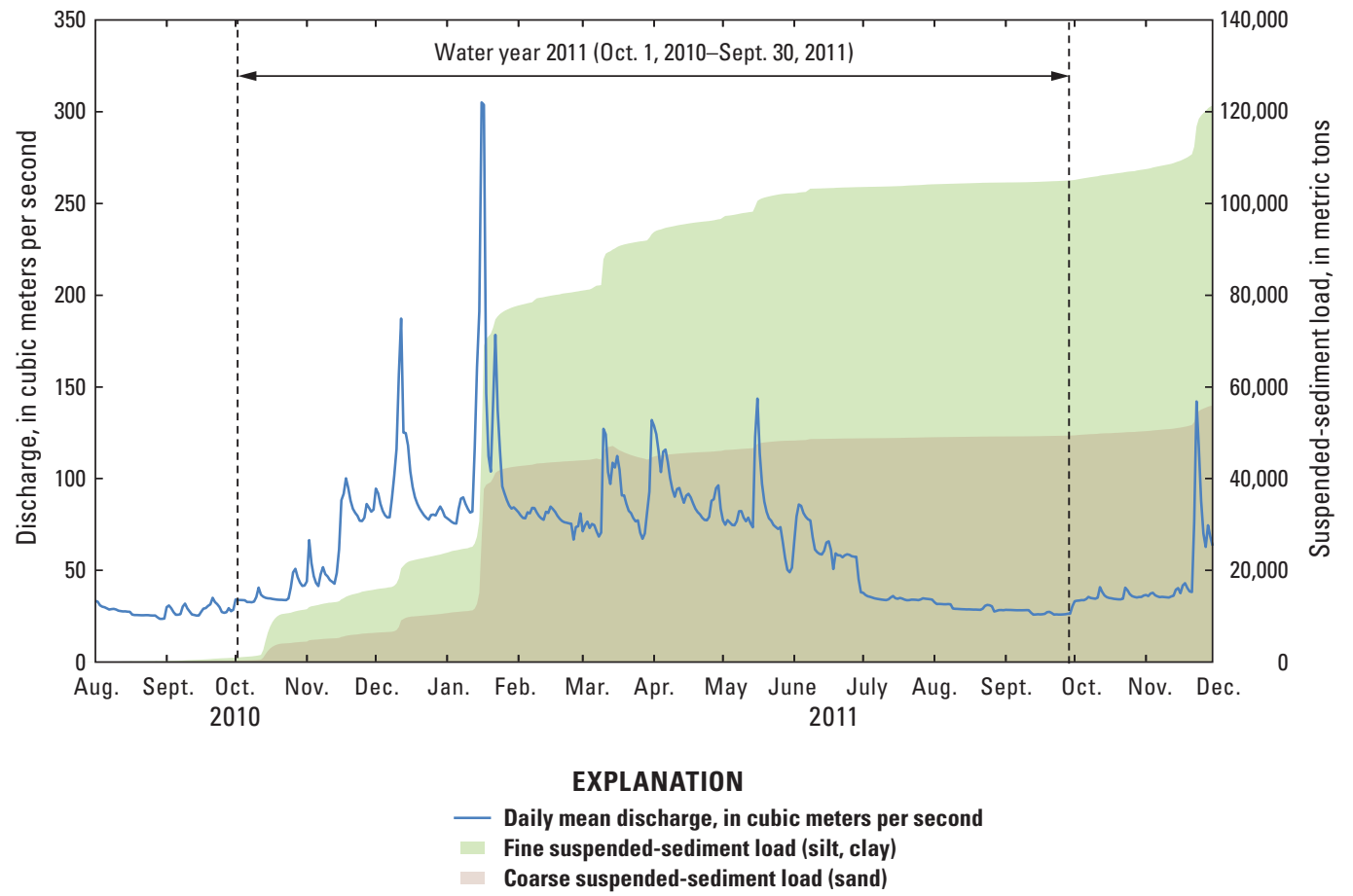

Figure 8. Discharge and cumulative suspended-sediment load calculated for sedimentmonitoring site (Nisqually River near Yelm, 12089970), western Washington, water year 2011. 


\section{Comparison with Previous Estimates of Suspended-Sediment Load}

The concentrations of EDI and EWI samples collected in this study (table 3) were used with concurrently measured or estimated discharge to develop by regression a sedimentrating curve for estimating suspended-sediment load as a function of discharge. A similar curve was developed using suspended-sediment concentrations and discharges reported graphically by Nelson (1974) and shown in table 4. Because regression models defining each curve were similar, the data were combined to develop a single sediment-rating curve (fig. 9) for the purpose of estimating suspended-sediment load at the sediment-monitoring site (Nisqually River near Yelm, 12089970). The model that defines the sediment-rating curve is:

$$
L_{s}=0.00199 Q^{2.68} b c f
$$

where

$L_{\mathrm{s}} \quad$ is the suspended-sediment load in metric tons per day ( $\mathrm{t} / \mathrm{d})$, and

$Q \quad$ is the discharge in cubic meters per second, and $b c f$ is the bias correction factor equal to 1.17 .

The coefficient of determination for the model $\left(R^{2}\right)$ is 0.85 , the p-value is 6.7E-13, and the number of observations is 30 . Bias correction for the model output, required as a result of log-transforming regression variables and model uncertainty (Helsel and Hirsch, 1992; Rasmussen and others, 2009) was calculated using a parametric method (Ferguson, 1986) described in Helsel and Hirsch (1992).

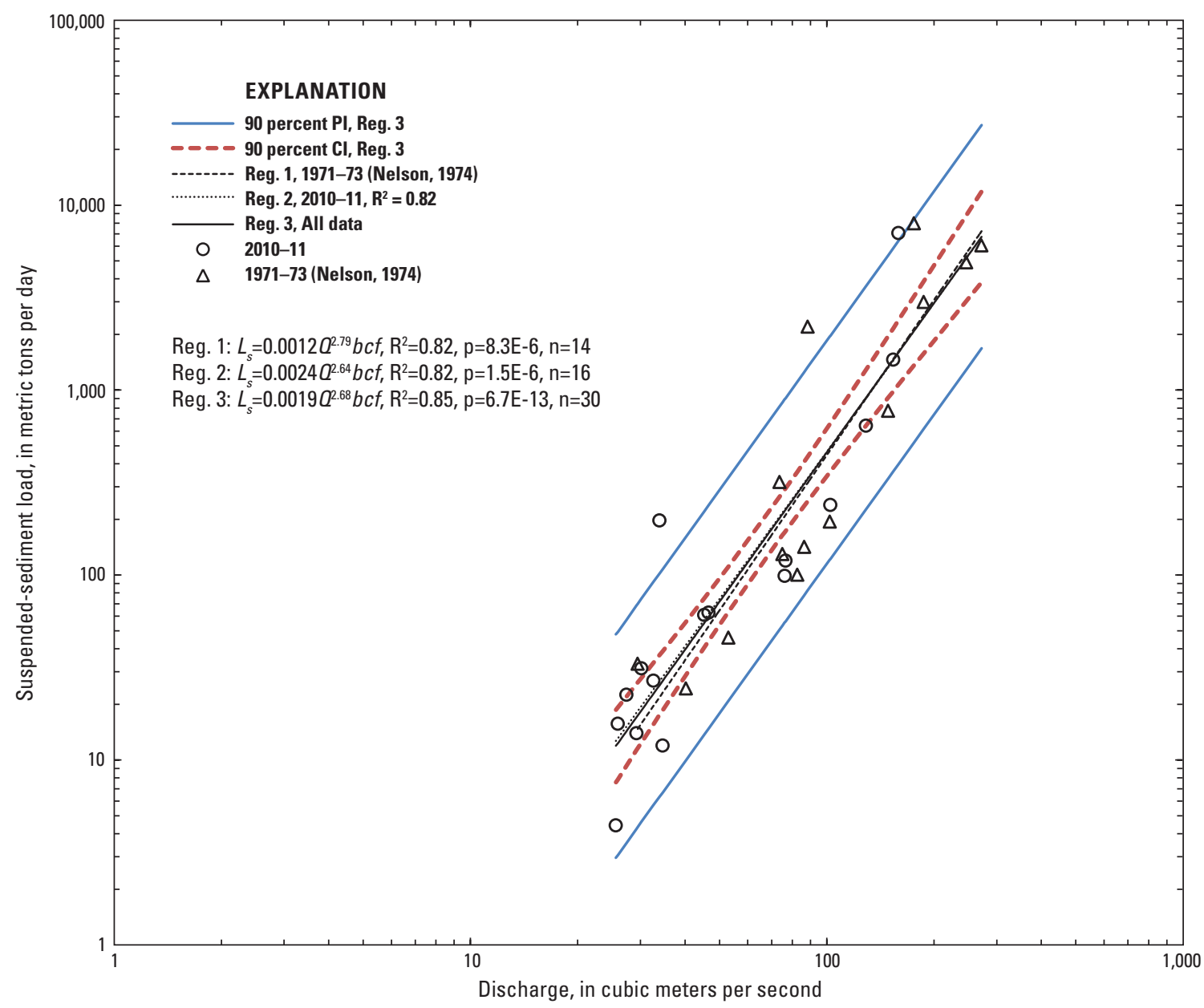

Figure 9. Regression model for estimating suspended-sediment load $\left(L_{s}\right)$ from river discharge (Q) at sediment-monitoring site (Nisqually River near Yelm, 12089970), western Washington. Model was based on combined sediment data from this study and Nelson (1974) (Reg., regression model; $\mathrm{PI}$, prediction interval for individual estimates; $\mathrm{Cl}$, confidence interval for the regression mean; bcf, bias-correction factor equal to $1.17 ; \mathrm{R}^{2}$, coefficient of determination; $\mathrm{p}, \mathrm{p}$-value; $\mathrm{n}$, number of observations). 
Table 4. Suspended-sediment concentrations and discharges reported by Nelson (1974) for samples collected at the Nisqually River near Nisqually, Washington, 1971-73, and computed suspended-sediment load used in developing a sediment-rating curve.

[Abbreviations: $\mathrm{mg} / \mathrm{L}$, milligram per liter; $\mathrm{m}^{3} / \mathrm{s}$, cubic meter per second; $\mathrm{t}$, metric ton]

\begin{tabular}{rccc}
\hline $\begin{array}{c}\text { Sample } \\
\text { No. }\end{array}$ & $\begin{array}{c}\text { Suspended- } \\
\text { sediment } \\
\text { concentration } \\
\text { (mg/L) }\end{array}$ & $\begin{array}{c}\text { Water } \\
\text { discharge } \\
\left(\mathbf{m}^{3} / \mathbf{s}\right)\end{array}$ & $\begin{array}{c}\text { Suspended- } \\
\text { sediment load } \\
\text { per day } \\
\mathbf{( t )}\end{array}$ \\
\hline 1 & 534 & 176 & 8,120 \\
2 & 288 & 88.4 & 2,200 \\
3 & 257 & 272 & 6,040 \\
4 & 230 & 246 & 4,900 \\
5 & 185 & 187 & 2,990 \\
6 & 60 & 149 & 771 \\
7 & 50 & 73.7 & 318 \\
8 & 22 & 102 & 194 \\
9 & 20 & 75.1 & 130 \\
10 & 19 & 86.4 & 142 \\
11 & 14 & 82.7 & 100 \\
12 & 13 & 29.5 & 33 \\
13 & 10 & 53.0 & 46 \\
14 & 7 & 40.2 & 24 \\
\hline
\end{tabular}

Using the combined sediment-rating curve $(\mathrm{n}=30)$ for the sediment-monitoring site (Nisqually River at Yelm, 12089970) and an estimated annual suspended-sediment contribution of 1,500 t from Muck Creek, average annual suspended-sediment load delivered by the lower Nisqually River to Puget Sound is estimated at 99,000 $\mathrm{t} / \mathrm{yr}$, with an uncertainty range of -37 to +54 percent (62,000-152,000 t/yr) at 90 percent confidence. This estimate is based on the combined record of daily discharges from water years 1980-2014 at McKenna (12089500) and the Centralia Power Canal (12089208) when discharges at both streamgages were reported (fig. 10; http://waterdata.usgs.gov/wa/nwis/sw). For comparison, the sediment-rating curve applied in water year 2011 resulted in an annual sediment load of 119,000 t, or 14 percent more than the load derived from the combined turbidity and Isco sample data in water year 2011.

The maximum annual suspended-sediment load for water years 1980-2014 was estimated at 580,000 $t$ for water year 1996, and the maximum 2-day total for this year was $250,000 \mathrm{t}$. The median annual load of 73,000 $\mathrm{t}$ is substantially less than the average $(99,000 \mathrm{t}$ ), and the correlation (Pearson's $r=0.80, p=8.1 \mathrm{E}-9, n=35$ ) between annual maximum 2-day sediment loads and normalized peak discharges for the period (water years 1980-2014; fig. 10) indicates the importance of wet years and associated peak discharges of the lower Nisqually River for sediment delivery to Puget Sound.

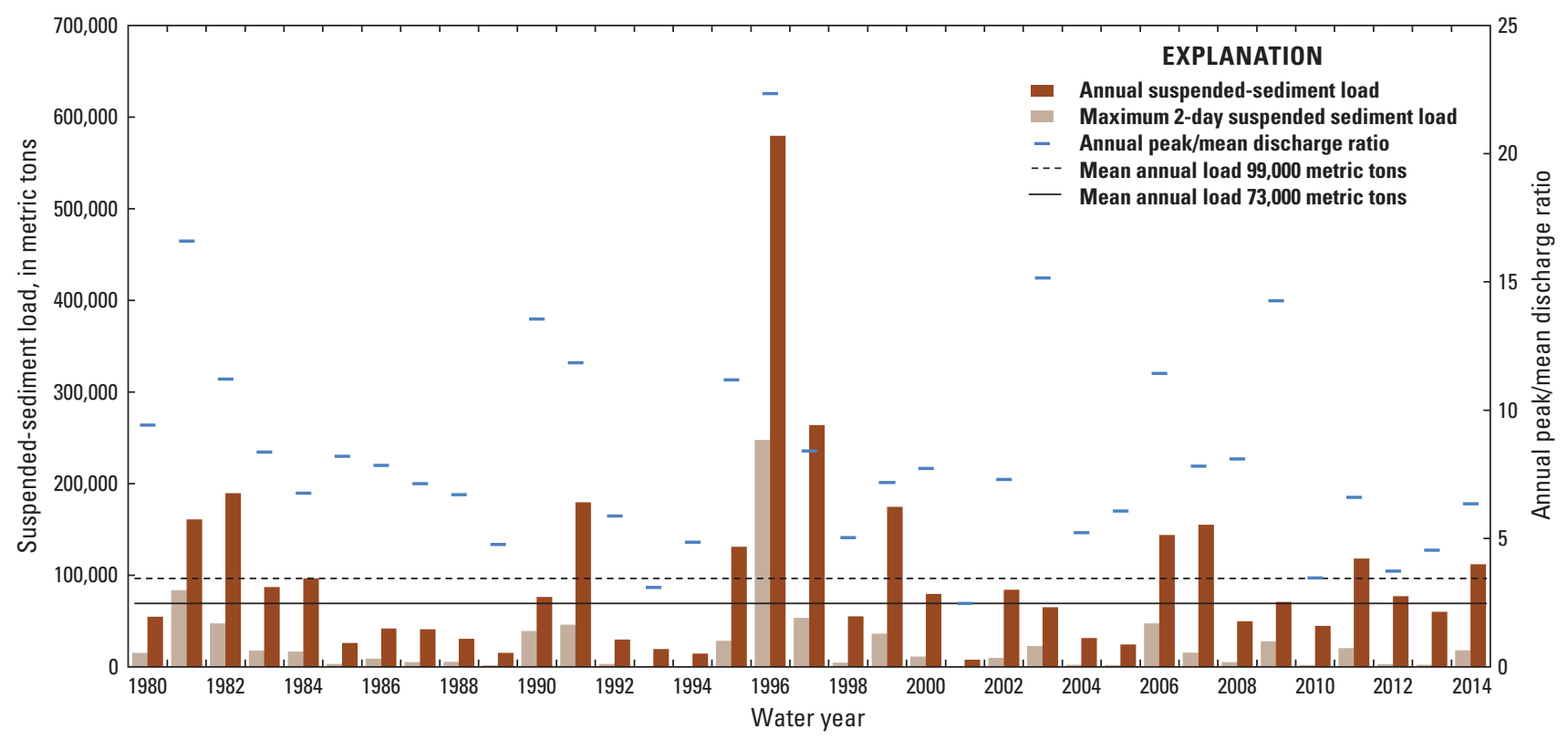

Figure 10. Annual and maximum 2-day totals of suspended-sediment load at sediment-monitoring site Nisqually River near Yelm (12089970), and the ratio of annual peak discharge to annual mean discharge at streamgage Nisqually River at McKenna (12089500), western Washington, water years 1980-2014. 


\section{Summary}

This report documents the timing and quantity of suspended-sediment load delivered by the Nisqually River to Puget Sound in water year 2011 (October 1, 2010September 30, 2011), for use in conjunction with nearshore circulation models to assess the sedimentation potential and efficacy of restoration efforts in the Nisqually River Delta. For water year 2011, daily sediment and continuous turbidity data were used to determine that 106,000 metric tons ( $\mathrm{t}$ ) of suspended sediment was delivered to Puget Sound (104,000 $t$ at Nisqually River near Yelm, Washington, and an estimated 2,000 $\mathrm{t}$ from Muck Creek), and 36 percent of this load occurred in 2 days of a typical winter storm. Mean discharge in the Nisqually River upstream and downstream of reservoirs was about 30 percent greater than average, and monthly mean discharge was greater than average for all months except February, which was average. The magnitude of peak discharges in the lower Nisqually River generally is dampened by flow regulation and reservoirs, which trap sediment. Of the total suspended-sediment load delivered to Puget Sound in water year 2011, 47 percent was sand (particle size $>0.063$ millimeters), and the remainder (53 percent) was silt and clay. A sediment-transport curve developed from suspended-sediment samples collected during 2010-11 agreed closely with a curve derived in 1973 using similar data-collection methods, indicating that similar sediment-transport conditions exist. Using the transport curve, the mean annual suspended-sediment load delivered by the lower Nisqually River near Yelm to Puget Sound is estimated at $99,000 \mathrm{t} / \mathrm{yr}(-37$ to +54 percent at 90 percent confidence) for water years 1980-2014. The sediment-transport curve applied to daily discharge in water year 2011 resulted in an annual suspended-sediment load that was 14 percent greater than the load determined using a combined turbidity and Isco sampler approach. The median annual suspended-sediment load of 73,000 $t$ is substantially less than the average load (99,000 t), and the correlation (Pearson's $r=0.80, p=8.1 \mathrm{E}-9$, $n=35$ ) between annual maximum 2-day sediment loads and normalized peak discharges for the period indicates the importance of wet years and associated peak discharges of the lower Nisqually River for sediment delivery to Puget Sound.

\section{Acknowledgments}

This study was supported by the USGS Coastal Habitats in Puget Sound Large River Deltas Project. We acknowledge the efforts of Steve Sumioka, Karen Payne, Greg Justin, Mathieu Marineau, and Mark Mastin of the USGS Washington Water Science Center for field assistance.

\section{References Cited}

Booth, D.B., 1994, Glaciofluvial infilling and scour of the Puget lowlands, Washington, during ice-sheet glaciation: Geology, v. 22, no. 8, p. 695-698.

Cereghino, P., Toft, J., Simenstad, C., Iverson, E., Campbell, S., Behrens, C., and Burke, J., 2012, Strategies for nearshore protection and restoration in Puget Sound: Washington Department of Fish and Wildlife, Olympia, Washington, and U.S. Army Corps of Engineers, Seattle, Washington, Puget Sound Nearshore Report No. 2012-01.

Collins, B.D., and Montgomery, D.R., 2011, The legacy of Pleistocene glaciation and the organization of lowland alluvial process domains in the Puget Sound region: Geomorphology, v. 126, nos. 1-2, p. 174-185, accessed June 4, 2013, at doi:10.1016/j.geomorph.2010.11.002.

Collins, B.D., Montgomery, D.R., Fetherston, K.L., and Abbe, T.B., 2012, The floodplain large-wood cycle hypothesis-A mechanism for the physical and biotic structuring of temperate forested alluvial valleys in the North Pacific coastal ecoregion: Geomorphology, v. 139-140, no. 0, p. 460-470, doi:10.1016/j.geomorph.2011.11.011.

Crandell, D.R., 1971, Postglacial lahars from Mount Rainier volcano, Washington: U.S. Geological Survey Professional Paper 677, 75 p. (Also available at http://pubs.er.usgs.gov/ publication/pp677.)

Czuba, J.A., Magirl, C.S., Czuba, C.R., Grossman, E.E., Curran, C.A., Gendaszek, A.S., and Dinicola, R.S., 2011, Sediment load from major rivers into Puget Sound and its adjacent waters: U.S. Geological Survey Fact Sheet, 2011-3083, 4 p.

Czuba, J.A., Olsen, T.D., Czuba, C.R., Magirl, C.S., and Gish, C.C., 2012a. Changes in sediment volume in Alder Lake, Nisqually River Basin, Washington, 1945-2011: U.S. Geological Survey Open-File Report 2012-1068, 30 p.

Czuba, J.A., Magirl, C.S., Czuba, C.R., Curran, C.A., Johnson, K.H., Olsen, T.D., Kimball, H.K., and Gish, C.C., 2012b, Geomorphic analysis of the river response to sedimentation downstream of Mount Rainier, Washington: U.S. Geological Survey Open-File Report 2012-1242, 134 p. (Also available at http://pubs.usgs.gov/of/2012/1242/.)

Davis, B.E., 2005, A guide to the proper selection and use of federally approved sediment and water-quality samplers: U.S. Geological Survey Open-File Report 2005-1087, 26 p. 
Edwards, T.K., and Glysson, D.G., 1999, Field methods for measurement of fluvial sediment: U.S. Geological Survey Techniques of Water-Resources Investigations, book 3, chap. C2, 89 p.

Ferguson, R.I., 1986, River loads underestimated by rating curves: Water Resources Research, v. 22, no. 1, p. 74-76.

Helsel, D.R., and Hirsch, R.M., 1992, Statistical methods in water resources: New York, Elsevier, 522 p.

Koltun, G.F., Eberle, M., Gray, J.R., and Glysson, D.G., 2006, User's manual for the Graphical Constituent Loading Analysis System (GCLAS): U.S. Geological Survey Techniques and Methods, book 4, chap. C1, 51 p.

Mueller, D.S., Wagner, C.R., Rehmel, M.S., Oberg, K.A., and Rainville, Francois, 2013, Measuring discharge with acoustic Doppler current profilers from a moving boat (ver. 2.0, December 2013): U.S. Geological Survey Techniques and Methods, book 3, chap. A22, 95 p., http:// dx.doi.org/10.3133/tm3A22.

National Oceanic and Atmospheric Administration, 2010, Climate of Washington: National Oceanic and Atmospheric Administration Western Regional Climate Center Web site, accessed August 24, 2012, at http://www.wrcc.dri.edu/ narratives/WASHINGTON.htm.

Neiman, P.J., Schick, L.J., Ralph, F.M., Hughes, M., and Wick, G.A., 2011, Flooding in western Washington-The connection to atmospheric rivers: Journal of Hydrometeorology v. 12, p. 1,337-1,358, doi:10.1175/2011JHM1358.1.

Nelson, L.M., 1974, Sediment transport by streams in the Deschutes and Nisqually River Basins, Washington, November 1971-June 1973: U.S. Geological Survey Open-File Report 74-1078, 33 p.

Porter, S.C., and Swanson, T.W., 1998, Radiocarbon age constraints on rates of advance and retreat of the Puget lobe of the Cordilleran Ice Sheet during the last glaciation: Quaternary Research, v. 50, no. 3, p. 205-213.
Porterfield, G., 1972, Computation of fluvial-sediment discharge: U.S. Geological Survey Techniques of WaterResource Investigations, book 3, chap. C3, 66 p.

Rasmussen, P.P., Gray, J.R., Glysson, G.D., and Ziegler, A.C., 2009, Guidelines and procedures for computing time-series suspended-sediment concentrations and loads from in-stream turbidity-sensor and streamflow data: U.S. Geological Survey Techniques and Methods, book 3, chap. C4, 53 p.

Scott, K.M., Vallance, J.W., and Pringle, P.T., 1995, Sedimentology, behavior, and hazards of debris flows at Mount Rainier, Washington: U.S. Geological Survey Professional Paper 1547, 56 p. (Also available at http:// pubs.er.usgs.gov/publication/pp1547.)

Sisson, T.W., and Vallance, J.W., 2008, Frequent eruptions of Mount Rainier over the last 2,600 years: Bulletin of Volcanology, v. 71, no. 6, p. 595-681, doi:10.1007/s00445008-0245-7.

U.S. Fish and Wildlife Service, 2010, Estuary restorationThe return of the Nisqually Delta: U.S. Fish and Wildlife Service brochure, 2 p., accessed May 10, 2013, at http:// nisquallydeltarestoration.org/pdf/Est_Rest_BroOct.10.pdf.

Veilleux, A.G., Cohn, T.A., Flynn, K.M., Mason, R.R., Jr., and Hummel, P.R., 2014, Estimating magnitude and frequency of floods using the PeakFQ 7.0 program: U.S. Geological Survey Fact Sheet 2013-3108, 2 p., accessed March 10, 2014, at http://dx.doi.org/10.3133/fs20133108.

YSI Incorporated, 2007, E56-6136-Turbidity-sensor, technical specification sheet: YSI Incorporated Web site, accessed May 5, 2011, at http://www.ysi.com/accessoriesdetail. php?6136-Turbidity-Sensor-6-Series-94. 
This page intentionally left blank. 


\section{Appendixes}

Appendixes A-D are Microsoft ${ }^{\circledR}$ Excel files and are available for download at http://dx.doi.org/10.3133/sir20165062.

Appendix A. Daily Suspended-Sediment Concentrations and Loads at Nisqually River near Yelm, Washington (USGS Sediment Monitoring Site 12089970), July 25, 2010-November 30, 2011.

Appendix B. Continuous 15-Minute Turbidity Data at Nisqually River near Yelm, Washington (USGS Sediment Monitoring Site 12089970), July 25, 2010-November 30, 2011.

Appendix C. Data and Equations Used for Applying a Cross-Section Correction to SuspendedSediment Concentrations of Isco Pump Samples.

Appendix D. Regression Model Used for Estimating Suspended-Sediment Concentration from Discharge. 

Publishing support provided by the U.S. Geological Survey Science Publishing Network, Tacoma Publishing Service Center

For more information concerning the research in this report, contact the Director, Washington Water Science Center

U.S. Geological Survey

934 Broadway, Suite 300

Tacoma, Washington 98402

http://wa.water.usgs.gov 


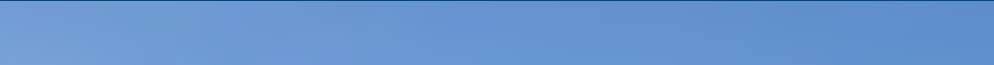

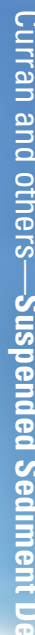

